\title{
Transport in times of an epidemic: public transport measures in the Czech Republic and its regions
}

\author{
Martin Vrána, Simona Surmařová, Petr Hlisnikovský, Jiř́i Dujka ${ }^{1}$
}

\begin{abstract}
In the first half of 2020, the global pandemic of the COVID-19 virus became a phenomenon affecting all spheres of human life. Measures against the spread of the virus have led to restrictions in life in public spaces and have also affected the transport sector. These impacts consisted of two types - firstly, the number of connections was reduced due to a drop in transport demand, and secondly, it was necessary to comply with hygiene measures on the part of carriers and passengers. The impacts of these measures could be monitored at all spatial levels, from global to local. This paper deals with the course of the so-called first wave of the pandemic in the Czech Republic in relation to public transport and its organization. The aim of the paper is to provide an overview of these measures in relation to general government regulations and their subsequent implementation at the national, regional (county) and local (selected large cities) level. Furthermore, the paper uses three case studies to show what changes long-distance domestic transport has undergone on selected routes. There was a significant reduction in the number of long-distance connections, some lines were not operated at all, and of course, all cross-border connections were canceled. The papercovers the period from the turn of February and March 2020, when the measures began to take effect, to the end of May 2020, when almost all the adopted measures were gradually relaxed. The paper concludes with a summary of the basic features of the organization of transport during the validity of the special mea sures, as well as areas where significant changes took place and whose consequences may persist after the pandemic subsides.
\end{abstract}

Keywords: COVID-19, epidemic, public health, public transport, restrictions, soft measures

JEL Classification: R40, R41, I18

Received: 6 October 2020 /Accepted: 21 December 2020 / Sent for Publication: 16 March 2021

\section{Introduction}

The viral pandemic of coronavirus labeled COVID-19 became a significant global phenomenon in the 1 st half of 2020. Its impact on human health, society and the economy is often compared to the pandemic of the so-called Spanish flu from the first half of the 20 th century. In most countries of the world, measures have been put in place to prevent the spread of the disease and reduce the number of victims. The free permeability of state

\footnotetext{
${ }^{1}$ Department of Economics, Faculty of Economics and Administration, Masaryk University, Brno, Czech Republic, vrana.martin@mail.muni.cz, simona.surmarova@gmail.com, petr.hlisnikovsky@mail.muni.cz, jiri.dujka@mail.muni.cz 
borders has been restricted and the complete closure of individual countries has often been carried out. These measures consist mainly in various degrees of spatial or social isolation, preventing in particular the concentration of a large number of people. There were closures of services, stores, shopping malls, the cancellation of sports, cultural and social events, and to a lesser extent also the reduction of industry.

In the Czech Republic, everyday life was also significantly affected in the form in which it functioned during the first two months of 2020. The aim of this paper is to present and describe the measures by which public transport in particular was restricted during the coronavirus pandemic in Czechia. The article focuses mainly on passenger bus and rail transport at the national level and at the level of individual regions (administrative and self-governing units). This division reflects the way in which public transport is organized in the Czech Republic, where regional public transport (rail and road) is ordered and operated within individual regions (NUTS 3). Long-distance rail transport on selected backbone lines is organized by the state (Ministry of Transport), long-distance bus transport in Czechia is handled exclusively by private carriers without conceptual coordination. Measures regulating the operation of urban public transport in the largest cities of the country are also outlined. Due to the high interconnectedness of individual regional levels (state - region - micro-region - city), these measures were usually similar.

The second part of the article presents three case studies concerning long-distance rail and bus transport. These studies are based on the analysis of the number of connections during the pandemic measures and their comparison with the state according to the standard timetable. In railway transport, the operation of the state carrier České dráhy is compared with the operation of two private carriers, RegioJet, which also operates longdistance bus transport, and Leo Express, on the busiest railway line in the country, Pra gue Ostrava. In bus transport, the approaches of the two majority long-distance bus carriers, the Czech company RegioJet and the international group FlixBus, were compared, and on selected lines also carriers specializing primarily in regional transport.

The article is not focused on thorough analyses of the situation and the possible impacts of the measures. A global pandemic of this nature is unique at the current stage of global civilization and is still ongoing, although emergency measures are being eased up (the situation in May 2020, when this article was written). It is, therefore, only possible to draw partial conclusions based on the description of the measure and the cross-sectional partial analysis rather than trying to address the whole problem. Road and rail freight transport was also not included in the analyzes.

\section{Public transportation under the epidemic influence}

The proper functioning of transport is a combination of quality a ssurance of the relevant infrastructure built for individual transport modes and suitable conditions for their operation. The safety and smoothness of traffic consist primarily in com plying with traffic rules and trying to maintain normal traffic without the occurrence of emergencies. However, there are una voidable events. The ability of transportation system s to cope with these emergencies is discussed in the literature through the concepts of vulnerability (Mattson, Jenelius, 2015; Mitsakis et a1., 2014), survivability (Mattson, Jenelius, 2015) and resilience (Woodburn, 2019; Mattson, Jenelius, 2015; Tamvakis, Xenidis, 2012). Rather, these concepts address their ability to overcome physical disruption and the 
difficulty of rebuilding the system (Mattson, Jenelius, 2015). It is not entirely clear whether these concepts can also be applied to transport restrictions during the corona virus epidemic, because it is a limitation on a scale that modern society has not experienced before, and a reason that has never been the cause of such extensive transport changes. Most disasters have direct destructive effects on infrastructure or create conditions in which material damage and life-threatening danger can occur in the form of traffic accidents or incidents. Such disruptions to the transport network lead to outages in the supply chain and it is necessary to look for alternative routes or ways to ensure the transport of goods (Kleindorfer, Saad, 2005) and people.

Emergencies are usually divided according to their origin into natural (earthquakes, hurricanes, tsunamis, volcanic eruptions, snowstorms, etc.) and man-made (traffic accidents, riots, political instability, terrorism). However, some may be of both origin s (floods, fires, or epidemics/pandemics) (Kleindorfer, Saad, 2005; Tansel, 1995). Other divisions define, for example, the probability of their occurrence (Taniguchi, Thompson, Yamada, 2010; Tansel, 1995) or a scale of the range (Tansel, 1995). If we focus on the relationship between transport emergencies and the scope, we find that most of these events are local or regional in scope. The literature deals mainly with their influence on transport infrastructure (Huibregtse et al., 2016; Da lziell, Nicholson, 2001; Pregnola to et al., 2017; Taniguchi, Thompson, Yamada, 2010) or changes in passenger transport behavior (Kvizda, Seidenglanz, 2014). With an increasing scale, the number of cases is declining and disasters on a global scale are rare in history, especially epidemics (plague, cholera, Spanish and bird flu, SARS, etc.). However, their frequency is still increasing in modern history (Tatem, Rogers, Hay, 2006). The gra dual development of transcontinental modes of transport (sea, rail, air), bringing the world together, and accelerating the transport of goods and people are helping to spread nationalepidemics to other countries, which may turn into globalpandemics. The ability to expand or the way it spreads through space can be a nother way of dividing emergencies.

Epidemics are unique among emergencies in that they do not cause material damage to infrastructure, but in the context of the supply chain, affect its safe provision by "attacking" the health of people (the workforce) without which it cannot function. Finding and securing alternatives is organizationally difficult because public transport is one of the exposed places to spread the virus in society. In the case of epidemics, transport mea sures are partly a voluntary and partly necessary decision of the competent authorities to serve as a tool to address the further spread of the epidemic.

The corona virus epidemic in 2002, known as SARS, was the first similar epidemic in the 21 st century. It is thus a good example of a comparison of transport behavior and measures implemented during a coronavirus epidemic. Air transport is considered essential for its worldwide expansion (Cherry, Krogstad, 2004). It was recorded in a total of 32 countries, but only in 6 of them were more than 50 cases identified in the end (WHO, 2003). However, the outbreak elicited a response at the international level. Coun tries restricted entry to citizens of countries with outbreaks, flights were canceled, special travel visas were introduced or measures a gainst the temporary return to these countries for foreign workers and students (Teo, Yeoh, Ong, 2005). Teo, Yeoh and Ong (2005) describe the situation inside Singapore during this epidemic and emphasize the general need to act responsibly as crucial in combating the spread of the epidemic. In the area of transport, allentrances to Singapore were equipped with temperature scanners, and people 
with fever had to remain in quarantine for 14 days. Public places, including public transport, were subject to the obligation to wear a mask (not observed due to temperature) and were also disinfected more often. Fear of infection led to a decrease in the number of both TAXI and public transport passengers (Teo, Yeoh, Ong, 2005). Wang (2014) describes a change in behavior and a decrease in the daily number of passengers in Taip ei, Taiwan, using the example of the backbone subway system, where at the time of the culmination, there was up to a $50 \%$ loss of passengers compared to the usual state in the given annual period. The gradual return of passengers showed a slower course than the previous decrease. However, other special measures in transport were not introduced.

Assuming that the epidemic is spreading through human-to-human transmission, it is logical in transport that long-distance public transport lines, especially airlines, are today the fastest way to spread the virus between continents and countries. At the national and regional levels, these are the busiest transport lines. Not only the means of transport themselves, but also the transport terminals are risky places of transmission. In a means of transport, the risk of transmission lies in the length of time spent with the infected person, in transport terminals in the totalnumber of passengers present and an increased possibility of contact with potentially infected persons (Xu, McCluskey, Cressman, 2013). The effective halting of the spread of the epidemic in transport depends above all on understanding the principles of the spread of the virus (Mangili, Gendreau, 2005; Morawska, Cao, 2020) and the behavior of society during danger(Moussaïd, 2013). The interconnection of these two areas leads to the introduction of mea sures aimed at reducing the likelihood of transmission during the use of public transport and related transport infra structure to create suitable conditions for the renewal of the supply chain through the safe transport of labor. Despite the protocols on the protection of the world environment and the global scale of the spread of the disease, there is no worldwide uniform procedure for dealing with an epidemic/pandemic (Teo, Yeoh, Ong, 2005). Although the affected countries think in a globalcontext, they address their situation individually and implement their own rules and measures to reduce the risk of transmission in transport and to ensure the safe functioning of the supply chain.

\section{Methods of research}

During the preparation of chapters "State measures on public transport" and "Measures in public transport implemented in the regions of the Czech Republic", an extensive search was carried out on the official websites of state administration bodies, regional self-governments and their companies organizing transport, as well as the websites of private carriers. At the state level, a summary of implemented measures and their chronological sequence was prepared, for which data were drawn mainly from official records of resolutions of the Government of the Czech Republic and the Ministry of Health as the main bodies in managing pandemic situations. At the regional level, data is obtained through a quantitative desk research, where the main sources were the websites of regional authorities or companies established by the region (managing integrated transport systems). Important sources were also the websites of individual carriers, i.e., public transport operators.

Based on the publicly published information on this website, a list of measures implemented in connection with COVID-19 was created and it was quantified in which 
regions these measures were implemented and when. In many cases, the regions did not provide information about the exact date of the introduction of individual measures. Therefore, the resulting table (Table 1) does not contain this data. Differences in terms of the measures were demonstrated by the timelines (Figure 1). The resulting list was verified by individual regional authorities or companies, which had the opportunity to supplement it with information that was not published on the website, or had already been deleted by the time the site was surveyed. The capital city of Prague and the Mora vianSilesian Region only referred to the websites for data verification. The websites are managed in different ways. On some, new information on COVID-19 was published through the common system of current news and traceable in the news archive. Other sites have created a special section dedicated only to current transport restrictions, which is gradually updated and does not contain information from the past.

The chapter "The effect of epidemic on transregional public connections" is the case study focused on the analysis of the change in the number of provided connections in two-way traffic, on selected train and bus lines, before and after the introduction of emergency measures. A common feature of all analyzed lines is the fact that more carriers are involved in providing transport. The data is drawn from the timetables that were available on the websites of individual carriers, or from the timetables on the IDOS websites. Wednesday (representative of working days) and Saturday (weekend) were chosen as the analyzed days.

The Prague - Ostrava line was chosen for the a nalysis of train connections, which provides an important connection between Prague and Northern Moravia and Silesia. The line is part of the second and third railway corridors and can currently be considered one of the railway arteries in the country.

Three routes were selected for the analysis of long-distance bus transport: Pra gue - Brno, Pra gue - Liberec and Brno - Kroměříž. The Prague - Brno route is a connection of the two largest cities in the Czech Republic, with the fastest long-distance connections being run almost exclusively along the main highway D1 and there is no direct competition with the railway (the railway between these cities is routed elsewhere). The Prague - Liberec route represents a connection of national importance between the capital and metropolitan city, with the fastest long-distance connections being operated mainly a long the D10 and D35 highways, and there is no comparably high-qua lity and fast railway connection to it. The Brno - Kroměříz route is a connection between a metropolitan city and a town of regional importance, with the fastest connections being operated on the D1 motorway, without a comparable railway alternative. However, parallel off-highway connections, serving cities and towns along the route, also play an important role on this route.

State measures on public transport

The effect of the COVID-19 coronavirus on transport in the Czech Republic first manifested itself in internationaltransport. The set of the following measures was aimed at preventing the uncontrolled infiltration and spread of corona virus from across the state border in Czechia. The basis for most of the resolutions adopted is the declaration of a state of emergency on 12 March (Gov-CZ, 2020a) and its gradual prolongation, which has made it possible to quickly take additional restrictive and relaxing measures in connection with the disease. 
Although the first three cases of coronavirus infection in Czechia were confirmed on 1 March (MZČR, 2020a), the first manifestation of transport restrictions was a resolution adopted on 3 February with effect from 9 February, when the government issued a ban on all flights to China, i.e., 12 connections per week (MZČR, 2020b; ČTK, 2020). A reduction in other direct flights to/from countries that were the main sources of potential coronavirus infection at the time, namely South Korea and Italy followed on March 5 (MZČR, 2020c; MZČR, 2020d). A turning point in international air transport was the adoption of Government Resolution No. 197 of 12 March, which, with effect from 14 March, meant the temporary reintroduction of internal air border protection, with the exception of Václav Havel International Airport in Prague and Kbely Military Airport (Gov-CZ, 2020b) and Resolution No. 198, which prohibits the entry of all foreigners from countries identified by the Ministry of the Interior of the Czech Republic as high-risk. The list of these states has been and still is being gradually updated. This resolution also completely suspends the processing (with approved exceptions) of international visas for entry (Gov-CZ, 2020c). These steps, together with the restriction of the free movement of citizens of the Czech Republic (Gov-CZ, 2020d), and thus their travel, had the direct effect of reducing demand and gradually reducing the total number of flights from/to countries outside the list of high-risk countries. The only routes in operation for the whole period remained air services to Sofia (Bulgaria) and Minsk (Belarus) (Prague Airport, 2020).

Simultaneously with the adoption of air border control, the land border control with Austria and Germany was reintroduced despite the Schengen area (Gov-CZ, 2020b) and with effect from 15 March this protection was extended to the borders with other states neighboring Czechia, i.e., Slovakia and Poland (Gov-CZ, 2020e). All legal movement across the state border was thus limited to selected border crossings. These measures were followed by a resolution of the Government of the Czech Republic adopted with effect from 14 March, banning all carriers in international road passenger transport provided by vehicles with a capacity of more than nine persons from carrying passengers across the borders of the country. Similarly, the resolution included a ban on all carriers in international rail passenger transport as well as in cross-border inland waterway passenger transport (Gov-CZ, 2020f). The aim of the restriction was to abolish all international public transport connections to/from the Czech Republic and thus gain greater control over the movement of people, especially when entering the country. Each person crossing the sta te border towards the country had to prove him self with a negative virus test or stay in domestic quarantine for 14 days. Thanks to these measures, individual car transport has become the only option for internationalcommuters, i.e., citizens going to work in a neighboring state on a daily basis for work. However, these persons a re subject to other measures restricting their free movement upon return to the country (Gov-CZ, 2020g).

Restrictions in internationaltransport and the closure of the state border were, therefore, the first to affect transport in the Czech Republic. The abolition of international pub lic transport connections (excluding direct services) has also affected domestic transport on certain routes. In domestic public transport, on 18 March the Czech government directly restricted only those connections which are organized and financed by the state. These are long-distance railway connections opera ted by the sta te ca rrier České dráhy a.s. (Gov CZ, 2020h; Gov-CZ, 2020i). Other long-distance bus and rail connections operated by private companies were not affected by this restriction. Limiting the number of connections by private carriers was a decision based on their own economic strategy. 
As mentioned above, the organization of domestic transport in the country is the responsibility of regional governments in particular and is provided by regional organizations that are transport organizers of both road and rail regional transport connections. This is the reason why the role of the state is rather a framework-based on when implementing measures in regional transport. The Government of the Czech Republic adopted general resolutions, which set the main goal of preventing the overall spread of the virus in society. It also affected national transport. In particular, it is Resolution No. 215 of 15 March, which, with effect from 16 March, prohibits, with certain exceptions, the free movement of persons throughout Czechia and orders persons residing in the country to restrict movement in publicly accessible places to the period necessary, to remain at their place of residence and to limit contacts with other persons to what is strictly necessary. This fundamental resolution had a significant impact, in particular, on the restriction of leisure travel (Gov-CZ, 2020g; Gov-CZ, 2020d). The two resolutions adopted on $18 \mathrm{March}$ are of a hygienic nature with the clear aim of preventing the spread of the virus in areas of frequent occurrence and circulation of persons. The first prohibits all persons from moving and staying in all places away from home, without respiratory protective equipment (nose, mouth) such as a mask, scarf, shawl or other means (Gov-CZ, 2020g) and the second resolution recommends all public transport operators to disinfect places which people often touch (especially door handles, handrails, door controls, hand grips, seat backs), at least after each ride (Gov-CZ, 2020j). On March 30 , a government resolution was issued imposing further restrictions on state-ordered connections, together with adjusting the method of selling tickets, transport and reservation documents in national transport so as to limit direct contact between passengers and employees of the carrier as much as possible. These same procedures were also recommended to the management of all regional self-governments to meet the current reduced passenger demand for public transport services (Gov-CZ, 2020k).

Following the general provisions, it can be stated that in addition to the forced restriction of international transport, the measures taken after the state of emergency on March 12 are a market response to restrictions on free movement and that the state only minimally interferes with transport clients and carriers in deciding what restrictions to introduce in transport. However, both municipalities and carriers must act in accordance with the generally adopted provisions.

\section{Measures in public transport implemented in the regions of the Czech Republic}

At the level of NUTS 3 regions and cities, the measures introduced largely follow up on national regulations. Most of the resolutions had a direct impact on the operation of public transport, whether it was a resolution restricting the free movement of persons, wearing protective equipment or disinfecting transport means. However, regions and individual carriers were able to approach these resolutions individually, which is why in ma ny cases the government's resolution is supported by a decree of the governors of individual regions.

A number of carriers and transport companies also introduced various measures, which were an extension of the general conditions set by the regional self-government. As a result, we have registered a total of 30 different soft measures taken in various regions to slow down the spread of COVID-19 in public transport. 
The introduced measures could be divided into six subgroups, which can, however, intersect (see Table 1). The first group includes the prevention of the physical spread of the virus, i.e., procedures to increase hygiene. This involves travelling only with the mouth and nose covered, which relies on the responsibility of passengers to comply with this rule. Other measures in this category may be applied by the carrier. These include increased disinfection of cars, disinfection of ticket vending machines, placement of disinfection dispensers, especially in railway stations or vehicles, ventilation of vehicles at final stops, automatic stopping at all stops (even with signaling), automatic door opening and prohibition of using the STOP button. The latter three measures seek to reduce the physical contact of passengers with the parts of the vehicles that are used frequently and are therefore more likely to transmit the infection. The last measure in this category is the provision of protective equipment to carriers from the region. The regions provided the carriers directly with masks, shields, disinfection, or other aids or contributed financially. The carriers then distributed them to drivers and other personnel who come into contact with the public.

The second identified purpose is the protection of personnel employed in the public transport sector. In connection with the COVID-19 infection, there was a decrease in the workforce in a number of companies for several reasons. One was the ordered 14-day quarantine after contact with a sick person. The second important reason was also the closure of schools (MZČR, 2020e), which forced many employees to leave the workplace temporarily due to childcare. Parents of children under the age of 13 are entitled to financial compensation from the state, the so-called nursing allowance (MPSV, 2020). In order to a void excessive staff losses and to make public transport operational, a ban on entry through the front door in buses was introduced and a front protection area for drivers was established,i.e. it was forbidden to sit in the seats in the row behind the driver. Other measures below could also be seen as protection of staff, in particular those related to the cancellation of passenger check-in.

Another category of restrictions imposed was the closure of premises and restrictions on physical contact, both between passengers and staff but also between passengers themselves. These included closing or changing the opening hours of some carriers' counters, restricting the operation of toilets in stations and closing contact and information points, which are mainly used to purchase subscription tickets and cards.

Due to the fact that the greatest contact, and thus the potentialspread of the virus, occurs in public transport during physical contact, a number of fare-related measures were introduced to prevent or minimize such contact (handing over tickets, cash, etc.) One of the most important measures was the abolition of check-in by train attendants and the abolition of driver check-in on buses on regional routes. Thanks to this, in systems where no other method of paying the fare was introduced, there was also the provision of free transport, which was often not directly advertised by carriers, although these situations occurred in practice. At the same time, check-in by the check-in device (e.g., automatic machine) at the front door was canceled. Carriers encouraged passengers to purchase travel documents online using a website or application. In transport means where the fare was not canceled, only visual inspection of the tickets was introduced. The finances also related to the compensation of unused fares, where the validity of documents was extended or the possibility of returning unused fares, for example due to the cancellation of used connections. 
One of the most important groups of measures in terms of public transport operation was the reduction of connections. This occurred mainly due to a reduction in demand for public transport, which was caused by the possibility of working from home, as well as the abolition of contact teaching at all types of schools, or by limiting a number of services throughout the country. Last but not least, public transport has also become a place where more people are present at one time, and thus, compared to individual transport, it has become riskier. There was a reduction in connections for bus and train lines as well as for urban public transport connections. A special case of the reduction of connections was the ban on transport to isolated municipalities, which mainly concerned the Olomouc Region, where several municipalities were closed, the first three of which were Uničov, Červenka and Litovel. Apart from the Olomouc Region, this also concerned one municipality in the Vysočina Region. The connections only passed through the municipalities without stopping, or they went a round them completely. As a result of the reduction of connections in railway transport, the number of passenger trains were reduced. However, to ensure the serviceability of some settlements, there were also cases where express trains stopped at more stops than specified in the original timetables.

The last group of introduced measures is the restriction of above-standard / recreational transport. Locally, the operation of cycle buses was suspended and the operation of ski buses was terminated earlier. At the same time, the operation of historical and tourist lines of trains, trams, cable cars and shipping wa not started or was canceled. However, these measures were implemented at a relatively low frequency.

Table. 1. Measures introduced against COVID-19 in public transport at the regional level in the Czech Republic in March and April 2020

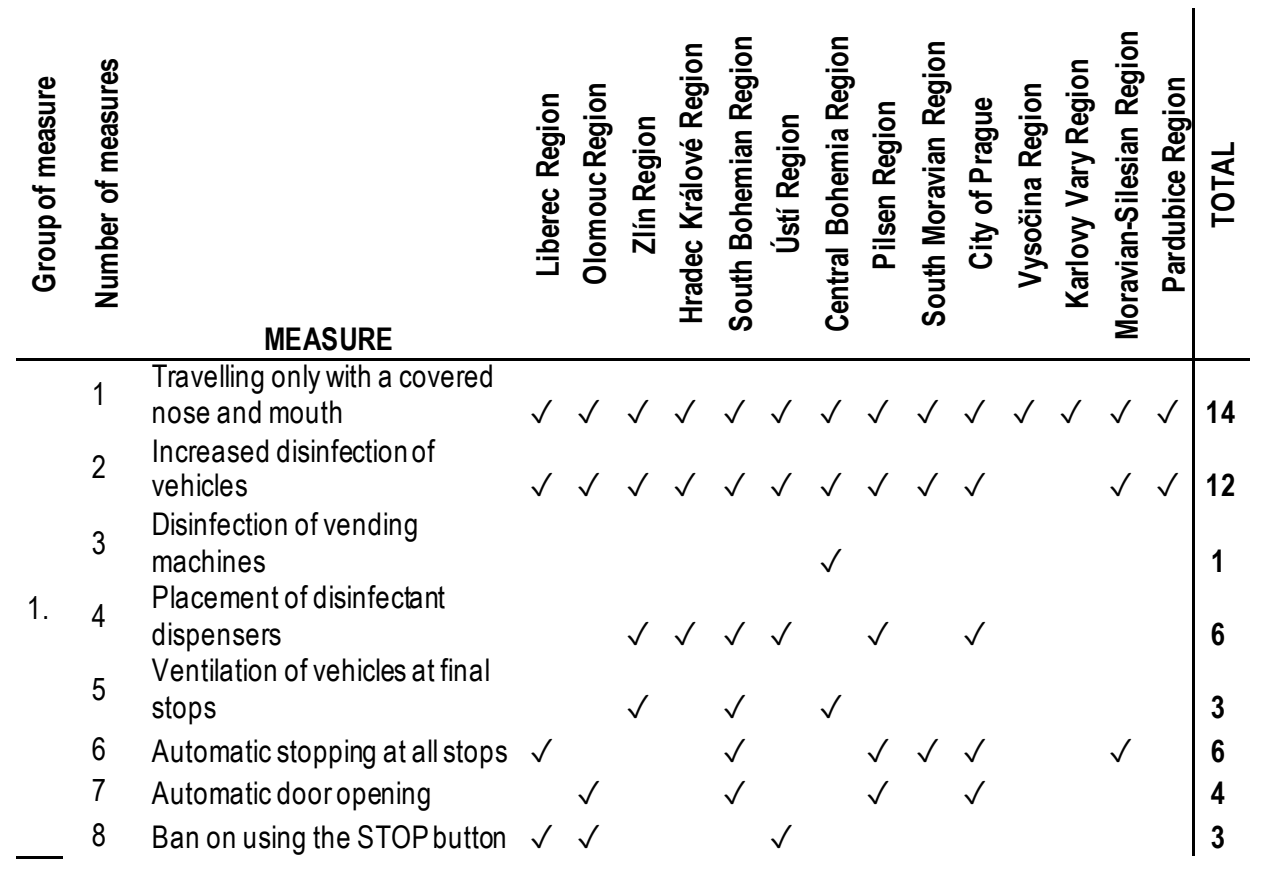


Provision of protective

9 equipment to carriers from the region

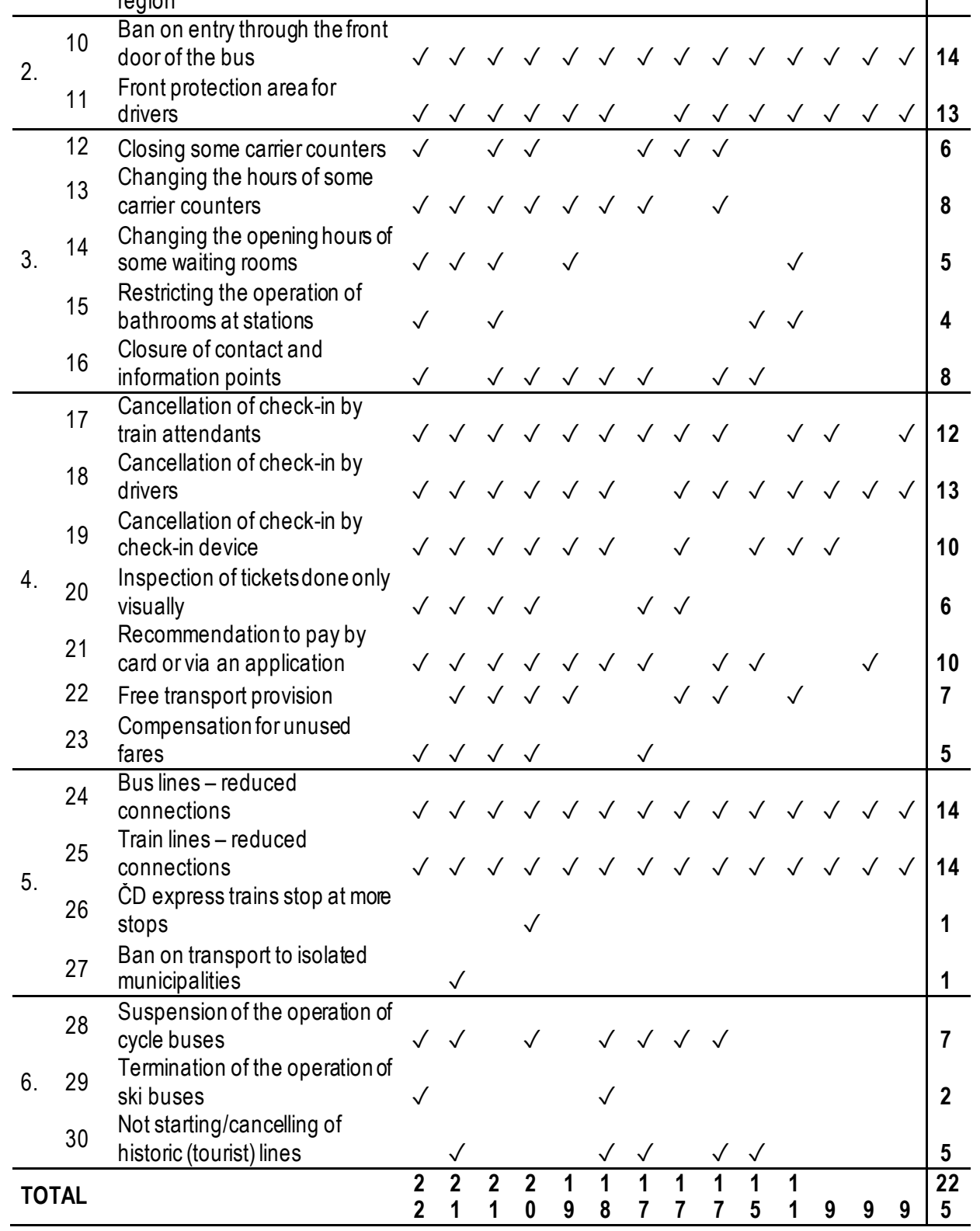

Source: Own research based on the official website of the NUTS 3 regions of the Czech Republic, integrated public transport systems and carriers

Note: The individual bars in the table indicate the different categories mentioned in the text above. 
The measures introduced against the spread of COVID-19 in public transport are summarized in Table 1. For each region, there is a column in the table that indicates whether the measure has been implemented. The measures are sorted according to the groups defined above, while the regions are sorted according to the number of implemented measures. In addition to the regional level, we also monitored the city level, which is not included in the table. As the city level is dedicated to the introduction of measures in urban public transport, primarily regional cities are taken into account, but actions in public transport of smaller cities have also been adopted.

The table shows that the activities related to COVID-19 were not broadly applied, with some exceptions, and did not occur in some regions. Only four measures were applied in all regions. These include travel with only the mouth and nose covered, a ban on entry through the front door of the bus and a reduction in the connections between bus and train lines. Very often, there was also the creation of a front protection area for drivers, the abolition of check-in by the driver and increased disinfection of cars. It therefore mainly involved measures to prevent the physical spread of the virus, to protect personnel and to reduce connections, which were unavoidable in all regions for the reasons described above. At the level of urban public transport, the situation is similar, the most frequently implemented measures concern the reduction of connections, travel with covered airways, disinfection of cars and protection of staff, namely the abolition of driver check-in and the ban on boarding through the front door.

The least implemented measures are cases that are mentioned rather individually in different regions according to their specific situation, are of a recreational nature, or are an extension of other more basic measures. For example, vehicle ventilation, a ban on the use of the stop button or automatic door opening can be an extension of the more widespread increased disinfection of vehicles. We can perceive, for example, the stopping of express trains at more stops or a ban on transport to isolated municipalities as localized events, because these municipalities were not located in the territory of all regions. Measures such as the limited operation of ski buses or cycle buses are of a recreational nature. The smaller number of their restrictions may also result from the fact that not all regions operate these services.

In addition to the measures implemented at the regional level, other measures were also identified that were implemented locally at the level of individual carriers or urban public transport. In the case of urban public transport, for example, the operation of senior buses was suspended. A significant number of companies opera ting urban public transport also started to reduce connections, similarly to the national and regional level. In particular, connections providing transport to schools or Sunday services were limited. Individual carriers also introduced some specific restrictions to combat the spread of the disease. An example is the national carrier České Dráhy, which abolished seat reservations and refreshments, reduced staff in cars and introduced the disinfection of stations, which also added information boards and leaflets with recommended procedures for people returning from areas affected by COVID-19.

In addition to the frequency of implementation of certain measures, the dates of their implementation also differ in individual regions. To demonstrate the significant differences, sample timelines of three mea sures implemented between 10, 15, and 22 days were created (see Figure 1). These mea sures were selected as they were presented in more 
than 12 regions, and at the same time, the speed of their implementation varies considerably. It is noticeable on the diagram that some regions reacted very quickly to one type of measure and reacted to others only later. However, it should be noted that the high speed of implementation of measures does not always coincide with the provision of the best services. For example, the later the regions reduced routes, the longer they tried to maintain a high quality of service for their passengers.

Figure 1. Timelines of selected measures introduced in the regions of the Czech Republic, 2020.
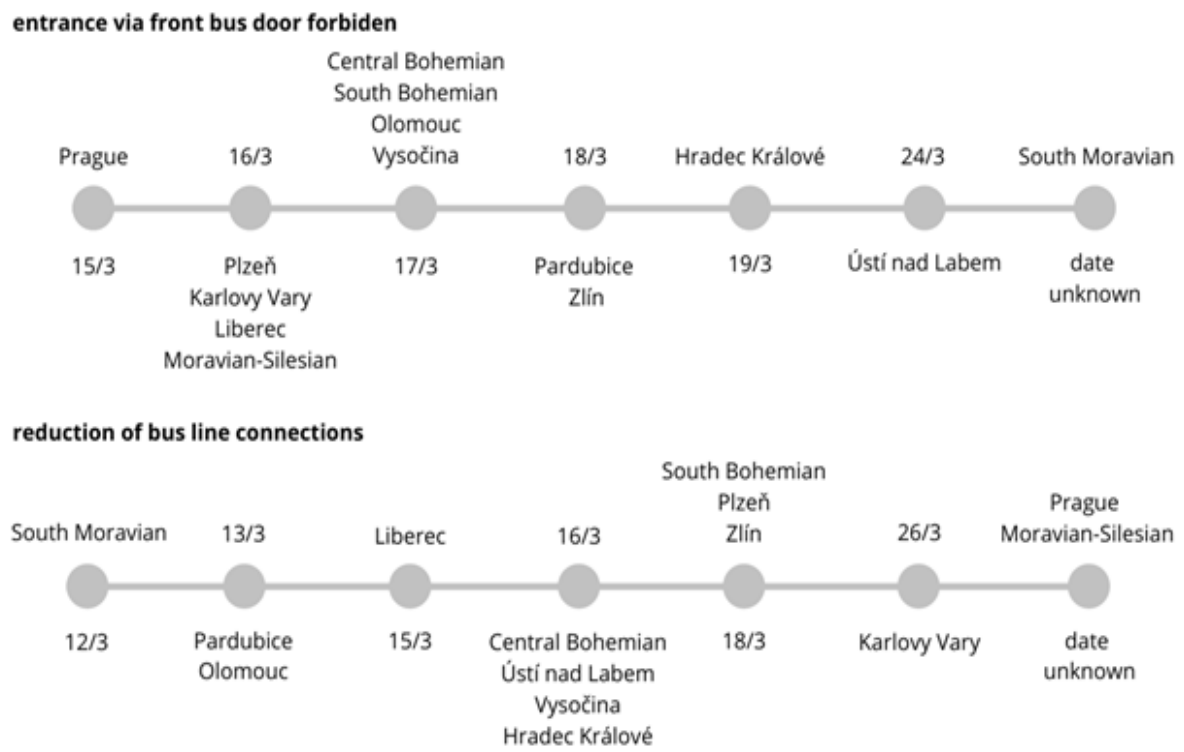

increased disinfection of vehicles

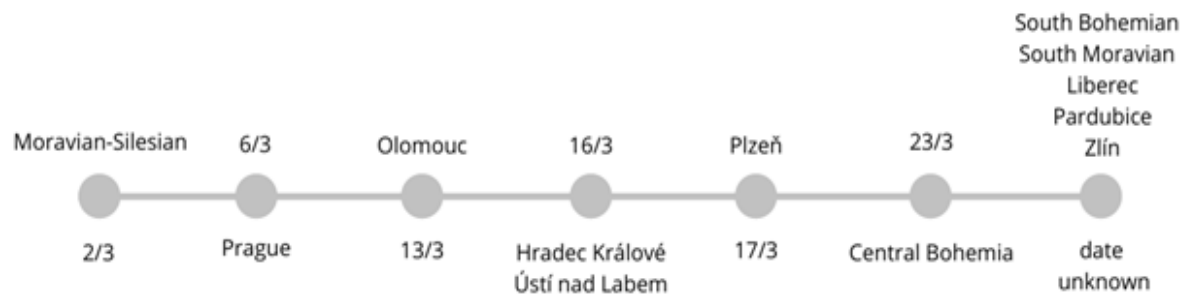

Source: Own research based on the official website of the regions of the Czech Republic, individual integrated public transport systems and carriers.

Apart from the diagram, there is also a special case of the introduction of a covered airway travel order, which all regions accepted within only four days (March 16-19). However, this measure is based on the national government resolution No. 247, which, effective from March 19, prohibits all persons from moving and staying in all places outside their place of residence without protective respiratory equipment (Gov-CZ, 2020g). Therefore, 
if the regions and carriers did not introduce this measure by March 19, it would apply to their passengers even without their direct order.

At the same time, it is worth mentioning that some regions introduced measures in advance of government regulations. As the regions are transport organizers, they have the opportunity to react flexibly to an unfolding situation. For similar reasons, the administration of some integrated transport systems also reacted earlier than the regions themselves.

Thus, it can be said that although individual regions have chosen different approaches and often different measures in the fight against COVID-19, all regions have sought to effectively protect passengers and employees in transport companies. The total number of measures in place varies considerably between regions. However, different regions informed about changes in transport in different ways. On the websites of regions and their integrated transport systems, there is often a continuous deletion of news and the display of only currently valid information, which could affect the absolute number of implemented measures. However, in order to avoid these fluctuations, the regions were contacted and asked to verify the data.

Our analysis shows that, within the Czech Republic, there are regions that were more active in the application of measures than others. Liberec Region introduced the largest number of measures, 22, Olomouc Region and Zlín Region followed with 21 measures, each. A total of 20 measures were introduced by the Hradec Králové Region. These regions have provided considerable protection to passengers and employees in operation. It is evident that the administration of the regional tra nsport departments, integrated public transport systems, carriers and therefore also the founders of urban public transport took the epidemiological situation seriously and did their utmost to minimize the spread of the virus and at the same time maintain the functioning of public transport.

In the fight a gainst COVID-19 in public transport, the regions of South Bohemian Region (19 measures), Ústí Region (18 measures), CentralBohemia Region (17 measures), Pilsen Region (17 measures) and South Moravian Region (17 measures) were active on an average to above-average level. For these regions, one could describe a strategy that introduces basic soft measures, similar to less active regions, but at the same time, there are also measures that can be perceived as superstructure (e.g., compensation of unused subscription fares; ventilation of vehicles at final connection stops) or relatively specific (e.g., termination of ski bus operation).

We could rate the City of Prague (14 measures) and the Vysočina Region (11 measures) as below average in their activity towards COVID-19. The Karlovy Vary Region, the Moravian-Silesian Region and the Pardubice Region each applied only nine measures. From the projection of the implemented measures of the three least active regions, it is possible to identify the absolute necessary minimum that had to be introduced: travelling only with a covered mouth and nose, no entry through the front door in the bus, front protection area for drivers, cancellation of driver check-in and the reduction of bus and train connections. It therefore involves a basic hygiene regulation, the protection of personnel and the reduction of connections as a necessary consequence of lower demand and sales. 
The activity of regions in measures applying was very different, but the anti-covid effect of every simple measure was not clear. The connection between the number of applied measures and positive cases per capita in regions, until April 30, was not really proved. In a short comparison between the most and least active regions, $0,056 \%$ of inhabitants were infected in the Zlín region and $0,051 \%$ in the Pardubice region. Although the difference between the number of applied measures is 12 , the amount of positive cases per capita is similar (MZČR, 2020a). On the one hand, it is a very simple way to verify such relation. On the other hand, the infection does not spread equally or only in public transport. That could be a great topic for another deeper analysis. The aim of this study was to provide an overview about applied measures and to present a different regional activity across the country.

\section{The effect of the epidemic on transregional public connections}

Extraordinary measures related to the fight against the coronavirus epidemic are manifested in public transport, mainly by a reduction in demand for it. Therefore, in response to the reduction in demand, carriers reduced the number of connections on individual domestic routes. This chapter discusses the extent to which the demand for transport has decreased or the number of connections during the day has decreased. The case study was performed on selected transport connections. Specifically, there was one train line Prague - Ostrava and three long-distance bus lines Prague - Brno, Prague Liberec and Brno - Kroměř́rž.

As we can see in Table 2, in the period before the emergency measures, a total of 62 connections traveled in both directions on working days between Prague and Ostrava. However, after the introduction of individual government mea sures, the conn ections were reduced to only 20 connections per day. In summary, we can talk about the cancellation of more than $2 / 3$ of all connections, with the most reductions being introduced by private carriers. Leo Express was forced to reduce the number of connections by more than $80 \%$. From the original 12 connections, it then operated only 1 connection in each direction. In addition, the connections were not operated at typical times of morning or afternoon peaks, but at times when other carriers rather canceled their connections (departure at 10.04 / 14.08). This suggests that the number of those being transported flattened out even during rush hours. RegioJet limited traffic from the original 18 connections to only 4 of them. With less than $78 \%$, the percentage reduction in connections is close to the values of Leo Express's competitors. České Dráhy has been forced to reduce the number of connections by approximately $56 \%$, which is significantly less than for private carriers. The connections were interrupted throughout the day and it was mainly the fastest and most luxurious layer of trains on the line - SuperCity Pendolino, which were completely canceled. Thus, instead of an 80-minute interval, České Dráhy vehicles ran every two hours. However, České Dráhy, unlike other carriers, runs a part of long-distance connections on the basis of an order from the state (Ministry of Transport) within the transport service of the territory, i.e., as a public obligation. Other carriers, which operate only commercialconnections, had to respond more to the decline in demand for transport. 
Table 2. Number of direct train connections between Prague and Ostrava (in both direction)

\begin{tabular}{lcccccc}
\multirow{2}{*}{ Company } & \multicolumn{2}{c}{ Before quarantine } & \multicolumn{2}{c}{ During quarantine } & \multicolumn{2}{c}{ Preserved (\%) } \\
& Wednesday & Saturday & Wednesday & Saturday & Wednesday & Saturday \\
\hline České Dráhy & 32 & 30 & 14 & 14 & 43.8 & 46.7 \\
RegioJet & 18 & 19 & 4 & 5 & 22.2 & 26.3 \\
Leo Express & 12 & 12 & 2 & 2 & 16.7 & 16.7 \\
\hline Total & $\mathbf{6 2}$ & $\mathbf{6 1}$ & $\mathbf{2 0}$ & $\mathbf{2 1}$ & $\mathbf{3 2 . 3}$ & $\mathbf{3 4 . 4}$ \\
\hline
\end{tabular}

Source: České dráhy (2017), REGIOJET (2020), Leo Express (2020), own calculation

The analysis of long-distance bus transport was performed in a similar way. There are only three bus operators that specialize exclusively in long-distance bus services, namely the domestic company RegioJet (formerly Student Agency), the international company FlixBus and Arriva, predominantly owned by the German company Deutsche Bahn. Long-distance transport in the Czech Republic is also operated on a smaller scale by regional carriers, but this is an ad hoc connection of the region (district) with the relevant facilities. For these connections, frequent maintenance was only in a partialroute or to a limited extent, but due to the specificity and fragmentation of this group of long-distance connections, the changes were not analyzed in more detail here.

However, the response to emergency measures for long-distance bus operators varied from route to route. An example is the carrier Student Agency, which did not restrict its connections on the Prague - Liberec route as it did on the Prague - Brno route. Prior to the measure, 16 connections were operated on the Prague - Brno line in each direction. However, the connections were reduced to only 3 , which represents a reduction in connections of approximately $81 \%$. The connections, which originally left the initial stop almost every hour, ran only once every 5 to 6 hours at the time of the measure. The reinforcements on Friday and Sunday connections for university students, who no longer had to commute to school due to the established distance learning, were also canceled.

Table 3. Number of direct bus connections between Prague and Brno (in both direction)

\begin{tabular}{lcccccc}
\multirow{2}{*}{ Company } & \multicolumn{2}{c}{ Before quarantine } & \multicolumn{2}{c}{ During quarantine } & \multicolumn{2}{c}{ Preserved (\%) } \\
& Wednesday & Saturday & Wednesday & Saturday & Wednesday & Saturday \\
\hline Student Agency & 32 & 32 & 6 & 6 & 18.8 & 18.8 \\
Flixbus & $\mathrm{x}$ & $\mathrm{x}$ & 0 & 0 & 0.0 & 0.0 \\
\hline Total & 32 & 32 & 6 & 6 & 18.8 & 18.8 \\
\hline
\end{tabular}

Source: CHAPS (2020), own calculation

Note: For FlixBus, pre-emergency measure timetables are not traceable

In contrast, on the Prague - Liberec route (see Table 4) in the period before the measures, there were a total of 43 connections of various lines during working days, which were reduced by only $28 \%$. Afterwards, there were 31 connections a day on the line. Moreover, in the case of this line, we cannot talk about a mere disruption of connections, as with the Prague - Brno line, as there was often only a reduction in journeys within days of the week. The connections that ran every day afterwards only ran on weekdays or only on 
weekends. At the same time, this adjustment of timetables ensured that, in most cases, two consecutive connections were in operation throughout the week. In practice, this means that if the connection at 9:00 am was run only on working days, the connection at 10:00 a m was run only on weekends. The German carrier FlixBus also operates transport on both of the above-mentioned routes, but it has suspended all domestic services in the Czech Republic.

Table 4. Number of direct bus connections between Prague and Liberec (in both direction)

\begin{tabular}{lcccccc}
\multirow{2}{*}{ Company } & \multicolumn{2}{c}{ Before quarantine } & \multicolumn{2}{c}{ During quarantine } & \multicolumn{2}{c}{ Preserved (\%) } \\
& Wednesday & Saturday & Wednesday & Saturday & Wednesday & Saturday \\
\hline Student Agency & 43 & 37 & 31 & 23 & 72.1 & 62.2 \\
Flixbus & $\mathrm{x}$ & $\mathrm{x}$ & 0 & 0 & 0.0 & 0.0 \\
\hline Total & 43 & 37 & 31 & 23 & 72.1 & 62.2 \\
\hline
\end{tabular}

Source: CHAPS (2020), own calculation

Note: For FlixBus, pre-emergency measure timetables are not traceable

Long-distance transport on the Brno - Kroměříž route is operated mainly by 3 carriers Student Agency, FlixBus and with a limited number of connections also Arriva. All three carriers have decided to suspend all connections on a given line, and, in the case of Student Agency, we can observe another of the approaches to responding to emergency measures. Regional and long-distance regional transport (partly along the motorway, partly off it) is operated by the carriers ČSAD Vsetín and Krodos. As we can see in Table 5, ČSAD Vsetín decided to cancel all connections on the given line. Krodos, which provides passenger transport mainly on working days, canceled about $37 \%$ of its connections. Mainly the connections outside the peak hours were disrupted. At the same time, transport was suspended all the way to Brno itself, with all connections in this direction starting/ending in Vyškov, which is a town about halfway along the route. Due to the fact that the Brno - Vyškov section (and back) is usually ridden along the D1 motorway as a long-distance route, the remaining connections on the Kroměříž - Vyškov route can be considered regional. In summary, connections between Brno and Kroměříž were reduced by more than $72 \%$ on working days and by $92 \%$ on weekends.

Table 5. Number of bus connections between Brno and Kroměříž (in both directions)

\begin{tabular}{lcccccc}
\multirow{2}{*}{ Company } & \multicolumn{2}{c}{ Before quarantine } & \multicolumn{2}{c}{ During quarantine } & \multicolumn{2}{c}{ Preserved (\%) } \\
& Wednesday & Saturday & Wednesday & Saturday & Wednesday & Saturday \\
\hline Student Agency & 6 & 4 & 0 & 0 & 0.0 & 0.0 \\
FlixBus & $\mathrm{x}$ & $\mathrm{x}$ & 0 & 0 & 0.0 & 0.0 \\
Arriva & 14 & 14 & 0 & 0 & 0.0 & 0.0 \\
Krodos & 19 & 2 & 12 & 2 & 63.2 & 100.0 \\
ČSADV Vetín & 4 & 4 & 0 & 0 & 0.0 & 0.0 \\
\hline Total & $\mathbf{4 3}$ & $\mathbf{2 4}$ & $\mathbf{1 2}$ & $\mathbf{2}$ & $\mathbf{2 7 . 9}$ & $\mathbf{8 . 3}$ \\
\hline
\end{tabular}

Source: CHAPS (2020), own calculation

Note: For FlixBus, pre-emergency measure timetables are not traceable. 
Unlike rail transport, long-distance bus transport in Czechia is operated exclusively at the risk of the carrier (with the exception of specific subsidies such as fares for schoolchildren or seniors) and is not ordered by the Ministry of Transport. However, some long-distance lines operating like non-express can be considered as regional thanks to their stop policy. In such ca ses, the region (NUTS 3) subsidizes part of that line on its territory as a regional service. Such subsidy could be a motivation for carriers to keep more operating connections. Carriers without such a contract could react to the situation and proceed more in economic terms. Cancellation of all FlixBus lines connections could be an example of such an economic stra tegy during COVID-19 epidemic. Czech carrier Student Agency chose a different strategy based on a friendly approach to customers and their loyalty to keep reduced connections on some exclusive lines without any other carrier despite no subsidies.

\section{Conclusion}

Compared to 2002, there is a clear difference between the consequences of the SARS and COVID-19 epidemics. Although it is a similar type of infection, the strength of the two epidemics is completely different. There were only 6 of 32 countries worldwide with more than 50 cases during SARS in comparison with more than 120 countries over 10 000 cases during COVID-19. However, the research of measures was performed during the first wave of the epidemic. Evidence of this may be the number and nature of measures implemented in the organization of (public) transport.

Due to the nature of the organization of public transport in the Czech Republic, transport measures were implemented mainly at the regional and local level. Nationwide government measures created a framework that was implemented by individual regions and subsequently required individual carriers. The mea sures differed only in details, such as the extent (degree) of disinfection of vehicles or the date from which the measures were introduced. Large cities also proceeded in a similar way within the scope of their urban public transport.

Many measures in public transport were introduced in the country, which were felt mainly by passengers, but also by transport companies, which had to make a number of adjustments to normal transport. These were mainly actions aimed at preventing the spread of the COVID-19 virus. A large number of restrictions were of a hygienic nature, related to fares and changes in traffic, but the emphasis was also placed on the protection of transport company personnel.

In response to these facts, connections on domestic and international routes were reduced. The difference between the two levels is that while domestic routes were often restricted due to insufficient demand, international routes encountered restrictions on the cross border movement of people.

The limited offer of connections was introduced for several rea sons. The main rea son was a reduction in demand - if possible, work from home was preferred, contact teaching was abolished, services were limited and citizens were encouraged not to go out unless absolutely necessary. The reduction in demand could also be linked to the fear of infection, as public transport is used by more people than individual transport and is therefore riskier. Transport companies thus had to start a viable operation from a financial 
point of view, also because the number of available employees decreased due to the COVID-19 pandemic.

Around Easter 2020, i.e., from the end of the first ten days of April, the gradual relaxation of the established measures began. At present, i.e., at the end of May 2020, the organization of society has formally returned to almost the pre-pandemic state. There are certain hygienic rules, such as the obligation to wear hygienic masks in certain places, increased emphasis on hand disinfection, safety distances of people, etc. Similarly, measures in transport were gradually relaxed and the number of connections increa sed to the level before the introduction of emergency measures. At present, long-distance bus connections and international land and air connections are limited, as the possibility of cross-border movement has still not been fully restored.

The question is how the presence of an epidemic will influence public transportation in the future. Even though it's not possible to estimate the next progress in travelbehaviour, we would like to give the matter a thought. The longer the pandemic lasts, the more people could get accustomed to a way of life, which is linked to higher interaction in the online environment. This could lead to less physical interaction and a smaller number of trips in general. One could prefer an individual means of transportation at the expense of public transport due to a smaller risk of infection. The potential return to public transportation use can be possible through an increa se of hygienic standards in comparison with the prepandemic state, vaccine development and accomplishing absolute control over the pandemic of COVID-19. The current pandemic situation is a warning for potentialfuture emergencies and we would like to think that the measures implemented during the first wave of the COVID-19 epidemic will serve as an example of how to deal with them.

Acknowledgements: The authors would like to thank Mgr. Daniel Seidenglanz, Ph.D. for finding the time to provide valuable insight into this topic, and also to the representatives from integrated public transport systems and regions included in this study, who kindly supported us in obtaining required information.

Funding: This article is the output of the project called "New Mobility - High-Speed Transport Systems and Transport-Related Human Behaviour", Reg. No. CZ.02.1.01/0.0/0.0/16_026/0008430, co-financed by the "Operational Programme Research, Development and Education"

Disclosure statement: No potentialconflict of interest was reported by the authors.

\section{References}

CHERRY, J. D., KROGSTAD, P., (2004). SARS: The First Pandemic of the $21 \mathrm{st}$ Century. Pediatric Research, 56(1), 1-5. DOI: 10.1203/01.PDR.0000129184.87042.FC

CHAPS (2020). IDOS - vývěsné jízdní řády [online]. Available 2020-05-05 from: http://www.portal.idos.cz/Search.aspx?c=7\&mi=2

ČESKÉ DRÁHY (2017). Line timetables [online]. Available 2020-05-04 from: https://www.cd.cz/en/jizdni-rad/tratove-jizdni-rady/ 
ČTK (2020). Czech News Agency. Lufthansa ruší kvůli koronaviru spojení s Čínou. E15.cz [online]. Available 2020-04-02 from: https://www.e15.cz/byznys/doprava-alogistika/lufthansa-rusi- kvuli-korona viru-spojeni-s-cinou-1366365

DALZIELL, E., NICHOLSON, A., (2001). Risk and Impact of Natural Hazards on a Road Network. Journal of Transportation Engineering, 127(2), 159-166. DOI: 10.1061/(ASCE)0733-947X(2001)127:2(159)

Gov-CZ (2020a). Government of the Czech Republic. Usnesení vlády České republiky ze dne 12. března 2020 č. 194 o vyhlášení nouzového stavu pro území České republiky [online]. Available 2020-04-02 from: https://apps.odok.cz/attachment/down/IHOABMNHPBSV

Gov-CZ (2020b). Government of the Czech Republic. Usnesení vlády České republiky ze dne 12. března 2020 č. 197 o doča sném znovuzavedení ochrany vnitřních hranic České republiky [online]. Available 2020-04-02 from: https://apps.odok.cz/attachmentIdown/IHOABMNHPHXW

Gov-CZ (2020c). Government of the Czech Republic. Usnesení vlády České republiky ze dne 12. března 2020 č. 198 o přijetí krizového opatření [online]. Available 2020-0402 from: https://apps.odok.cz/attachment///down/IHOABMNHPMSG

Gov-CZ (2020d). Government of the Czech Republic. Usnesení vlády České republiky ze dne 15. března 2020 č. 215 o přijetí krizového opatření [online]. Available 2020-0402 from: https://apps.odok.cz/attachment///down/IHOABMQVW63P

Gov-CZ (2020e). Government of the Czech Republic. Usnesení vlády České republiky ze dne 15. března 2020 č. 221 o doča sném znovuzavedeníochrany vniťrních hranic České republiky [online]. Available 2020-04-02 from: https://apps.odok.cz/attachment//down/IHOABMQVWNX8

Gov-CZ (2020f). Government of the Czech Republic. Usnesení vlády České republiky ze dne 12. března 2020 č. 200 o príjetí krizového opatření [online]. Available 2020-04-06 from: $\underline{\text { https://apps.odok.cz/attachment///down/IHOABMNHPRJX }}$

Gov-CZ (2020g). Government of the Czech Republic. Usnesení vlády České republiky ze dne 18. března 2020 č. 247 o přijetí krizového opatření [online]. Available 2020-0408 from: https://apps.odok.cz/attachment//down/IHOABMTK5CCN

Gov-CZ (2020h). Government of the Czech Republic. Usnesení vlády České republiky ze dne 18. března 2020 č. 244 k informa cio doča sném omezení provozu dálkových vlaků Českých drah, a.s. v objednávce státu [online]. Available 2020-04-08from: https://apps.odok.cz/attachment/-/ down/IHOABMTJNX5W

Gov-CZ (2020i). Government of the Czech Republic. Př́loha usnesení vlády ze dne 18. března 2020 č. 244 [online]. Available 2020-04-08 from: https://apps.odok.cz/attachment/-/down/IHOABMTJNZY5

Gov-CZ (2020j). Government of the Czech Republic. Usnesení vlády České republiky ze dne 18. bř̌zna 2020 č. 251 o doporučení provádět dezinfekci v některých veřejně prístupných prostorech [online]. Available 2020-04-08 from: https://apps.odok.cz/attachment///down/IHOABMTJPFDC 
Gov-CZ (2020k). Government of the Czech Republic. Usnesení vlády České republiky ze dne 30. března 2020 č. $335 \mathrm{k}$ minimalizaci dopado̊ pandemie koronaviru COVID 19 při zajišt'ování dopravní obslužnosti veřejnými službamiv přepra vě cestujících [online]. Available 2020-04-08 from: https://apps.odok.cz/attachment/-/down/IHOABN7SBR2O

HUIBREGTSE, E., NAPOLES, O. W., HELLEBRANDT, L., PAPROTNY, D., WIT, S., (2016). Climate change in a sset management of infrastructure: A riskba sed methodology applied to disruption of traffic on road networks due to the flooding of tunnels. European Journal of Transport and Infrastructure Research, 16(1), 98-113. DOI: $\underline{10.18757 / \text { ejtir.2016.16.1.3116 }}$

KLEINDORFER, P. R., SAAD, G. H., (2005). Managing Disruption Risks in Supply Chains. Production and Operations Management, 14(1), 53-68. DOI: 10.1111/j.19375956.2005.tb00009.x

KVIZDA, M., SEIDENGLANZ, D., (2014). Out of Prague: a week-long intermodal shift from a ir to rail transport after Iceland's Eyjafjallajökull erupted in 2010. Journal of Transport Geography,37, 102-111. DOI: 10.1016/j.jtrangeo.2014.04.014

LEO EXPRESS (2020). Train timetables [online]. Available 2020-05-05 from: https://www.leoexpress.com/en/where-we-go/timetables/train

MANGILI, A., GENDREAU, M. A., (2005). Transmission of infectious disea ses during commercial air travel. The Lancet, 365(9463), 989-996. DOI: 10.1016/S0140$\underline{6736(05) 71089-8}$

MATTSON, L-G., JENELIUS, E., (2015). Vulnerability and resilience of transport systems-A discussion of recent research. Transportation Research Part A: Policy and Practice, 81, 16-34. DOI: 10.1016/j.tra.2015.06.002

MITSAKIS, E., PAPANIKOLAOU, A., AYFADOPOULOU, G., SALANOVA, J., DOLL, C., GIANNOPOULOS, G., ZEREFOS, C., (2014). An integrated framework for linking climate change impacts to emergency a daptation stra tegies for transport ne tworks. European Transport Research Review, 6(2), 103-111. DOI: 10.1007/s12544-013-0114-0

MORAWSKA, L., CAO, J., (2020). Airborne transmission of SARS-CoV-2: The world should face the reality. Environment International, 139. DOI: $\underline{10.1016 / \text { i.envint } 2020.105730}$

MOUSSAÏD, M., (2013). Opinion Formation and the Collective Dynamics of Risk Perception. PLoS ONE, 8(12). DOI: 10.1371/journal.pone.0084592

MPSV (2020). Ministry of labour and Social Affairs of the Czech Republic. Ošetřovné [online]. Available 2020-04-06 from: https://www.mpsv.cz/osetrovne

MZČR (2020a). The Ministry of Health of the Czech Republic. COVID-19: Přehled aktuální situace v ČR. Onemocnění aktuálně [online]. Available 2020-04-02 from: https://onemocneni-aktualne.mzcr.cz/covid-19

MZČR (2020b). The Ministry of Health of the Czech Republic. Ochranné opa tření - zákaz letů z Č́ny. [online]. Available 2020-04-02 from: https://www.mzcr.cz/ochranneopatreni-zakaz-letu-z-ciny/ 
MZČR (2020c). The Ministry of Health of the Czech Republic. Ochranné opa tření - zákaz letů z Korejské republiky. [online]. Available 2020-04-02 from: https://www.mzcr.cz/ochranne-opatreni-zakaz-letu-z-korejske-republiky/

MZČR (2020d). The Ministry of Hea th of the Czech Republic. Ochranné opa tření - zákaz letů z Itálie. [online]. Available 2020-04-02 from: https://www.mzcr.cz/ochranne opatreni-zakaz-letu-z-italie/

MZČR (2020e). The Ministry of Health of the Czech Republic. Mimořádné opatření ze dne 10.3. 2020. [online]. Available 2020-04-02 from: https://www.fulsoft.cz/download/ fulsoft/covid19 2.pdf

MZČR (2020f). The Ministry of Health of the Czech Republic. Covid-19: Přehled aktuální situace pro kraje [online]. Available 2021-01-11 from: https://onemocneniaktualne.mzcr.cz/covid-19/kraje

Prague Airport (2020). Currently available destinations [online]. Available 2020-04-02 from: https://www.prg.aero/en/currently-available-destinations

PREGNOLATO, M., FORD, A., GLENIS, V., WILKINSON, S., DAWSON, R., (2017). Impact of Climate Change on Disruption to Urban Transport Networks from Pluvial Flooding. Journal of Infrastructure Systems, 23(4). DOI: 10.1061/(ASCE)IS.1943$\underline{555 X .0000372}$

REGIOJET (2020). Jízdní řády [online]. Available 2020-05-04 from: https://www.regiojet.cz/jizdni-rady-a-zasta vky/jizdni-rady/

TAMVAKIS, P., XENIDIS, Y., (2012). Resilience in Transportation Systems. Procedia - Social and Behavioral Sciences, 48, 3441-3450. DOI: 10.1016/j.sbspro.2012.06.1308

TANIGUCHI, E., THOMPSON, R. G., YAMADA, T., (2010). Incorporating risks in City Logistics. Procedia - Social and Behavioral Sciences, 2(3), 5899-5910. DOI: 10.1016/j.sbspro.2010.04.005

TANSEL, B., (1995). Natural and manmade disasters: accepting and managing risks. Safety Science, 20(1), 91-99. DOI: 10.1016/0925-7535(94)00070-J

TATEM, A. J., ROGERS, D. J., HAY, S. I., (2006). Global Transport Networks and Infectious Disease Spread. Advances in Parasitology, 62, 293-343. DOI: 10.1016/S0065$\underline{308 X(05) 62009-X}$

TEO, P., YEOH, B. S. A., ONG, S. N., (2005). SARS in Singapore: surveillance strategies in a globalising city. Health Policy, 72(3), 279-291. DOI: 10.1016/j.healthpol.2004.11.004

WANG, K-Y., (2014). How Change of Public Transportation Usage Reveals Fear of the SARS Virus in a City. PLoS ONE, 9(3). DOI: 10.1371/journal.pone.0089405

WHO (2003). World Health Organization. Summary table of SARS cases by country, 1 November 2002 - 7 August 2003 [online]. Available 2020-05-27 from: https://www.who.int/csr/sars/country/country2003 08 15.pdf?ua=1 
WOODBURN, A., (2019). Rail network resilience and operational responsiveness during unplanned disruption: A rail freight case study. Journal of Transport Geography, 77, 5969. DOI: $\underline{10.1016 / \text { i.jtrangeo.2019.04.006 }}$

XU, F., MCCLUSKEY, C. C., CRESSMAN, R., (2013). Spatial spread of an epidemic through public transportation systems with a hub. Mathematical Biosciences, 246(1), 164-175.DOI: $\underline{10.1016 / j . m b s .2013 .08 .014}$ 